\title{
Urządzenia pomiarowe parametrów wentylacyjnych i stężenia metanu oraz koncepcja kompleksowego monitorowania zagrożenia metanowego w rejonie ściany wydobywczej
}

\begin{abstract}
$W$ artykule scharakteryzowano zagrożenia metanowe występująe $w$ rejonach ścian wydobywczych kopaln głębinowych węgla kamiennego oraz podstawy ich zwalczania. Scharakteryzowano urzadzenia pomiarowe stosowane do pomiaru parametrów środowiska podziemnego $w$ rejonie eksploatacji. Przedstawiono wyniki badań dotyczacych wyznaczania poziomu zagrożenia metanowego $w$ rejonie ściany wydobywczej. Wyznaczono parametry metanowości wentylacyjnej, bezwzględnej i kryterialnej na podstawie ciaglych pomiarów parametrów wentylacyjnych i gazowych. Zaprezentowane wyniki badań sa efektem realizacji badawczego projektu europejskiego AVENTO (Zaawansowane narzędzia do kontroli wentylacji i emisji metanu).
\end{abstract}

Słowa kluczowe: systemy monitorowania, urzadzenia pomiarowe, zagrożenie metanowe, wentylacja kopalń, kopalnie węgla

\section{WSTĘP}

Podstawowymi źródłami metanu w kopalniach są ściany wydobywcze oraz drążone wyrobiska chodnikowe [1]. W celu określenia ilości wydzielającego się metanu zostały opracowane różnorodne metody. W polskim górnictwie w czasie projektowania i eksploatacji stosowana jest metoda opracowana przez Główny Instytut Górnictwa - Kopalnię Doświadczalną Barbara [2], opisująca zasady określania dopuszczalnej zawartości metanu w wyrobiskach rejonów eksploatacyjnych.

Bieżąca ocena prowadzona jest na podstawie pomiarów dokonywanych przez systemy monitoringu stężeń metanu oraz sygnalizowanych przekroczeń wartości progowych (dopuszczalnych). Zależy ona od wiedzy oraz aktywności dyspozytora i nie uwzględnia wpływu na zagrożenie metanowe istotnych źródłowych czynników wynikających z eksploatacji węgla, przewietrzania oraz odmetanowania. Podjęte przez dyspozytora decyzje oraz wyłączenia automatyczne energii następują więc w momencie, kiedy zagrożenie już powstało. Wszelkie głębsze analizy zagrożenia metanowego opracowane są przez specjalistów wentylacji ze stosunkowo dużym opóźnieniem wynikającym ze sposobu zbierania danych niezbędnych dla oceny. Podczas analizy rozważane są wpływy na zagrożenie metanowe takich czynników, jak urabianie węgla, strumienie metanu w powietrzu wentylacyjnym i rurociągu odmetanowania oraz zmiany parametrów wentylacyjnych (rozkład ciśnień i przepływu powietrza w rejonie). Analizy takie prowadzone są w cyklach dobowych i tygodniowych.

$\mathrm{W}$ artykule przedstawiono wyniki prac prowadzonych w Instytucie Technik Innowacyjnych EMAG, których celem było:

- szersze wykorzystanie danych pomiarowych z systemu monitoringu do bieżących obliczeń parametrów wentylacyjnych i zaburzeń gazowych w przypadku występowania zmierzonych zmian, 
- zbadanie możliwości oceny kompleksowej online stanu wentylacji i zagrożenia metanowego w rejonie ściany wydobywczej na podstawie obliczanych metanowości (kryterialnej, wentylacyjnej i odmetanowania).

\section{CHARAKTERYSTYKA URZADZEŃ POMIAROWYCH}

Systemy monitorowania zagrożeń wentylacyjnych w kopalniach węgla kamiennego realizują pomiary w trzech podstawowych dziedzinach [3, 4]:

- zagrożenia metanowego,

- zagrożenia pożarowego,

- wybranych parametrów sieci wentylacyjnej.

Do pomiaru środowiska podziemnego w rejonie eksploatacji używane są następujące czujniki: temperatury, ciśnienia barometrycznego, prędkości przepływu powietrza oraz koncentracji metanu pracujących w systemie stosowanym $\mathrm{w}$ danej kopalni (np. SMP, CST [12]).

Czujniki wchodzące w skład systemu pomiarowego to:

- metanomierze - różnych typów, które stanowią samodzielne dołowe urządzenia pomiarowe i są podłączone bezpośrednio do obwodów wyjściowych centrali powierzchniowej,

- metanomierze - do podłączenia z centralką dołową,

- tlenomierze stacjonarne,

- czujniki do pomiaru temperatury i wilgotności powietrza,

- ultradźwiękowe anemometry stacjonarne,

- czujniki różnicy ciśnień - dla tam oraz dla wentylatorów głównych.

W badaniach wykorzystano również przenośne czujniki parametrów powietrza wentylacyjnego:

- prędkości przepływu powietrza,

- ciśnienia bezwzględnego,

- stężenia metanu.

Szczególnie istotne jest monitorowanie rejonów ścian wydobywczych, gdzie zachodzą najszybsze zmiany w wyrobiskach oraz górotworze. Stacjonarne pomiary metanu w wyrobisku roboczym ściany, ciśnienia bezwzględnego, temperatury i wilgotności oraz różnic ciśnień pozwolą na ciągłe monitorowanie mierzonych wielkości oraz obliczania parametrów pochodnych (jak metanowość) i szybkie reagowanie na zagrożenie.

\subsection{Przegląd czujników i urządzeń pomiarowych parametrów wentylacyjnych i stężenia metanu stosowanych w kopalniach}

Poniżej przedstawiono najczęściej stosowane w polskich kopalniach węglowych urządzenia do pomiarów parametrów wentylacyjnych $[12,13]$. W wykazie nie brano pod uwagę urządzeń do wykrywania pożarów oraz jakości atmosfery, takich jak: tlenomierze, czujniki tlenku węgla, dwutlenku węgla czy innych gazów, z wyjątkiem pomiaru metanu.

1. Czujniki do pomiaru temperatury i wilgotności powietrza.

- Pomiar wilgotności:

- czujnik wilgotności CW-1 produkcji EMAG, zasilany ze stacji dołowej, pomiar wilgotności przeskalowany na wyjście napięciowe $0,4-2,0 \mathrm{~V}$.

- Pomiar temperatury:

- czujnik temperatury górotworu CTG-2 produkcji EMAG, zasilany ze stacji dołowej, pomiar temperatury przeskalowany na wyjście napięciowe 0,4-2,0 V.

- Pomiar wilgotności i temperatury:

- czujnik wilgotności, temperatury i ciśnienia z cyfrową transmisją danych DHT produkcji EMAG-SERWIS,

- czujnik wilgotności i temperatury CSHT-1 produkcji Haso, współpracujący głównie z centralą telemetryczną typu CST-40(A) w zakresie transmisji i przekazywania danych,

- czujnik wilgotności i temperatury CSHT-2 produkcji Haso, współpracujący z centralą telemetryczną typu CST-40(A) poprzez centralkę analogową CSA-1,

- systemowe czujniki typu SC-PS, przeznaczone do ciągłego pomiaru temperatury, wilgotności powietrza i ciśnienia bezwzględnego produkcji Carboautomatyka, posiadają możliwość pracy w trzech standardach transmisji (z sygnałem cyfrowym FSK, napięciowym 0,4-2 V lub 1-5 V, kodowanym częstotliwościowo 5-12 kHz),

- iskrobezpieczny czujnik temperatury i wilgotności TH produkcji Sevitel z transmisją cyfrową poprzez konwerter KTM-1,

- czujnik wilgotności względnej MIC6410x wraz z pomiarem temperatury produkcji Micon.

2. Anemometry stacjonarne:

- anemometr stacjonarny TX5922 - ultradźwiękowy czujnik prędkości przepływu powietrza firmy TROLEX w zakresie 0,5-30 m/s działający na zasadzie vortex, polski dystrybutor firma Micon, 
- anemometr stacjonarny AS-2 (AS-3) produkcji EMAG, zasilany ze stacji dołowej, pomiar prędkości powietrza w zakresie $0-15 \mathrm{~m} / \mathrm{s}$ przeskalowany na wyjście napięciowe $0,4-2,0 \mathrm{~V}$ lub sygnał prądowy 4-20 mA,

- anemometr AS-3ES do ciągłego pomiaru prędkości przepływu powietrza, zasilany jest napięciem stałym zasilacza iskrobezpiecznego, generuje sygnał wyjściowy w standardzie napięciowym, produkcji EMAG-SERWIS,

- anemometr AS-4ES do ciągłego pomiaru prędkości przepływu powietrza, zasilany jest ze stacji powierzchniowej za pomocą linii telefonicznej, po której odbywa się transmisja danych, urządzenie produkcji EMAG-SERWIS,

- anemometr CSV-5 jest przyrządem stacjonarnym służącym do pomiaru prędkości i określenia kierunku przepływu powietrza za pomoca przetwornika termicznego, urządzenie dodatkowo mierzy temperaturę i wilgotność powietrza, produkcji Haso,

- stacjonarny anemometr skrzydełkowy SAS-5 (SAT-1) do ciągłego pomiaru prędkości przepływu powietrza, produkcji Instytutu Mechaniki Górotworu PAN, transmisja częstotliwościowa lub napięciowa do współpracy ze stacją dołową,

- stacjonarny anemometr skrzydełkowy MPP do ciągłego pomiaru prędkości przepływu powietrza, produkcji Instytutu Mechaniki Górotworu PAN, dystrybucja Carboautomatyka, anemometr mierzy także temperaturę otoczenia.

3. Czujniki do pomiaru ciśnienia atmosferycznego pod ziemią:

- stacjonarny iskrobezpieczny barometr mikroprocesorowy BM-2 produkcji EMAG, przeznaczony do współpracy z centralą powierzchniową, posiadający akumulator podtrzymujący działanie urządzenia,

- stacjonarny czujnik parametrów fizycznych powietrza THP-1 produkcji EMAG, przeznaczony do współpracy z centralą powierzchniową, posiadający akumulator podtrzymujący działanie,

- stacjonarny czujnik parametrów fizycznych powietrza THP-2 produkcji EMAG-SERWIS na licencji EMAG, dokonuje precyzyjnych pomiarów ciśnienia bezwzględnego, temperatury oraz wilgotności powietrza,

- czujnik DPT produkcji EMAG-SERWIS, przeznaczony do ciągłego monitorowania wilgotności względnej i temperatury powietrza oraz ciśnienia atmosferycznego, zasilany ze stacji powierzchniowej za pomocą linii telefonicznej,
- czujnik ciśnienia atmosferycznego, wilgotności i temperatury CSPA-2 produkcji Haso, przeznaczony do pomiaru ciśnienia bezwzględnego oraz wilgotności względnej, temperatury, współpracować może z centralą telemetryczną typu CST-40(A) poprzez centralkę analogową CSA-1 lub CSA-2; czujnik zasilany jest ze źródła iskrobezpiecznego o napięciu $12 \mathrm{~V}$.

4. Czujniki pomiaru różnicy ciśnień:

- czujnik różnicy ciśnień CRC-4 (CRC-5, CRC-6) produkcji EMAG, zasilany ze stacji dołowej, pomiar różnicy ciśnień przeskalowany na wyjście napięciowe 0,4-2,0 V lub przystosowany do transmisji częstotliwościowej,

- miernik różnicy ciśnień MRC0250 do MRC7500 produkcji EMAG, zasilany ze stacji dołowej, pomiar różnicy ciśnień przeskalowany na wyjście napięciowe $0,4-2,0 \mathrm{~V}$,

- czujnik różnicy ciśnień DRC produkcji EMAG-SERWIS, zaprojektowany do ciaggego monitorowania różnicy ciśnień w kopalniach, zasilany jest ze stacji naziemnej za pomocą linii telefonicznej,

- dwustanowy czujnik różnicy ciśnień MIC1303 produkcji MICON, służy do kontroli różnicy ciśnień pomiędzy dwoma punktami pomiarowymi,

- systemowe czujniki typu SC-RC przeznaczone do ciągłego pomiaru różnicy ciśnienia produkcji Carboautomatyka, mają możliwość pracy w trzech standardach transmisji (z sygnałem cyfrowym FSK, napięciowym 0,4-2 V lub 1-5 V, kodowanym częstotliwościowo 5-12 kHz).

5. Metanomierze stacjonarne do pomiarów ciągłych:

- czujnik metanomierza mikroprocesorowego CMM-1 produkcji EMAG,

- metanomierz mikroprocesorowy MM-1/V1 (MM-2) produkcji EMAG,

- czujnik metanomierza wysokich stężeń CMW-1 produkcji EMAG,

- metanomierze serii TX3261, TX6321 i MIC6321 produkcji Micon,

- iskrobezpieczny metanomierz stacjonarny IMS-1 produkcji Sevitel,

- metanomierz CSM-1 wersja R do pomiaru zawartości metanu w rurociagach odmetanowania w kopalniach węgla kamiennego produkcji Haso,

- infraredowy czujnik stężenia metanu CSM-3i (CSM-3m) produkcji Haso,

- pellistorowy czujnik stężenia metanu CSM-1 (CSM-3) produkcji Haso,

- systemowe czujniki typu SC-CH4/n, SC-CH4/s, SC-CH4/IR przeznaczone do ciągłego pomiaru stężenia metanu w powietrzu produkcji Carboautomatyka, 
- systemowe czujniki typu SC-CH4/W +CWx-3 przeznaczone do ciągłego pomiaru stężenia metanu w rurociaggach odmetanowania produkcji Carboautomatyka.

6. Metanomierze ręczne:

- przenośny sygnalizacyjny czujnik stężenia gazu MPS-1R produkcji Haso,

- metanomierz przenośny PMM-1 produkcji Sevitel.

Autorzy zdają sobie sprawę, że w artykule nie zostały wymienione wszystkie urządzenia dostępne na rynku. Przedstawione urządzenia do pomiaru parametrów wentylacyjnych oraz stężenia metanu są najczęściej stosowane w polskim górnictwie węgla kamiennego.

\section{BADANIA W REJONIE ŚCIAN WYDOBYWCZYCH}

\subsection{Urządzenia pomiarowe wykorzystane podczas badań w kopalni}

\subsubsection{Metanomierz MM-4}

Do pomiaru metanu wykorzystano standardowe urządzenie pracujące w większości polskich kopalń węgla kamiennego. Przyrząd typu MM-4 (rys. 1) charakteryzuje się dobrymi własnościami metrologicznymi i krótkim czasem odpowiedzi. Metanomierz MM-4 wykorzystuje klasyczną i najbardziej rozpowszechnioną zasadę pomiaru stężenia metanu z zastosowaniem przetworników termokatalitycznych zwanych pelistorami.

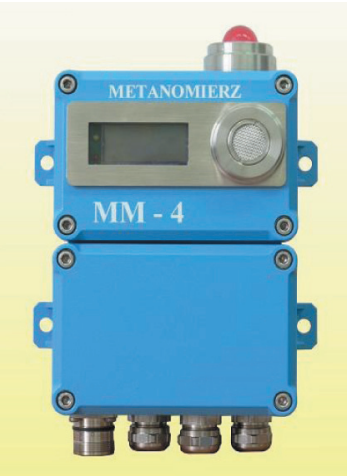

Rys. 1. Metanomierz MM-4

wykorzystywany $w$ badaniach

\subsubsection{Anemometr stacjonarny}

Anemometr AS-3 (rys. 2) przeznaczony jest do ciągłego pomiaru prędkości przepływu powietrza w chodnikach kopalnianych, tunelach, korytarzach.
Współpracuje z centralami dołowymi. Opracowany został w dwóch wersjach:

- w wersji AS-3n (z wyjściem napięciowym),

- w wersji AS-3c (z wyjściem prądowym).

Do pomiaru prędkości wykorzystano czasową metodę ultradźwiękową. Anemometr AS-3 może być użyty także doraźnie jako urządzenie przenośne, zasilany z iskrobezpiecznego zasilacza akumulatorowego.

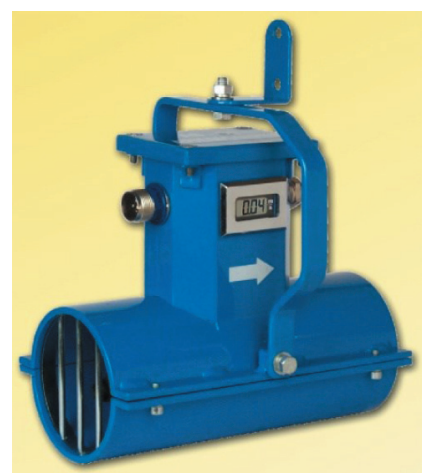

Rys. 2. Anemometr stacjonarny typu AS-3

\subsubsection{Czujnik parametrów fizycznych powietrza THP-2}

Stacjonarny czujnik parametrów fizycznych powietrza THP-2 (rys. 3) dokonuje precyzyjnych pomiarów ciśnienia bezwzględnego, temperatury oraz wilgotności powietrza. Konstrukcję czujnika oparto na małogabarytowym przetworniku ciśnienia SETRA 278 o wysokiej dokładności oraz półprzewodnikowym detektorze temperatury i wilgotności z wyjściem cyfrowym. Oprogramowanie czujnika umożliwia wielopunktową korekcję charakterystyki przetwarzania oraz współpracę z centralą powierzchniową w systemie metanowo-pożarowym.

Czujnik parametrów fizycznych powietrza typu THP-2 charakteryzuje się bardzo dobrymi jakościowymi i ilościowymi parametrami metrologicznymi. $\mathrm{Na}$ podstawie wskazań czujnika możliwe jest wyznaczanie potencjałów aerodynamicznych.

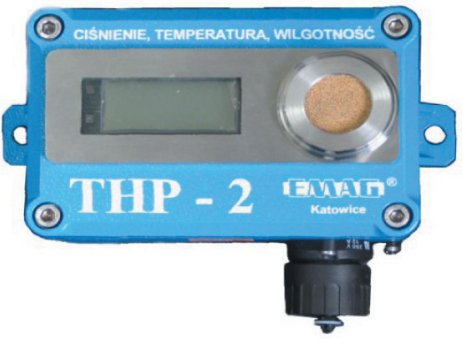

Rys. 3. Czujnik parametrów fizycznych powietrza typu THP-2 


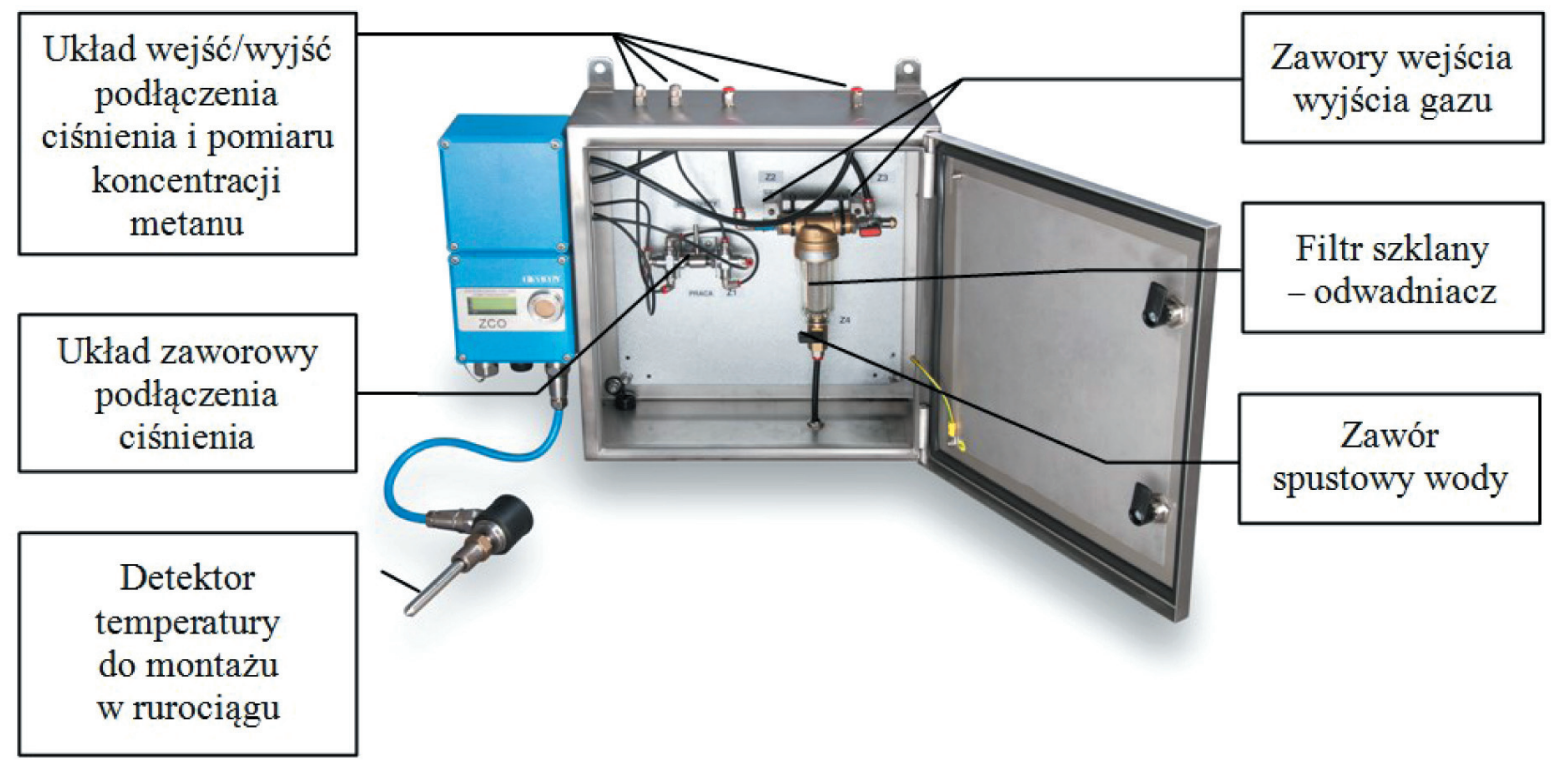

Rys. 4. Zintegrowany czujnik odmetanowania typu ZCO

\subsubsection{Urządzenie do pomiarów parametrów odmetanowania}

Zintegrowany czujnik odmetanowania typu ZCO (rys. 4) służy do pomiaru ilości ujmowanego metanu [9]. Montowany jest obok rurociagu odmetanowania i przewodami pneumatycznymi podawane jest medium do komory pomiarowej. Wykonuje pomiary parametrów fizycznych (ciśnienie, różnica ciśnień na kryzie, temperatura) i koncentracji metanu w rurociągu. Produkowany jest w dwóch wersjach: dla systemu SMP-NT oraz niezależnego systemu z transmisją zgodną z interfejsem RS-485 i osobnym iskrobezpiecznym zasilaniem.

$\mathrm{Na}$ podstawie wykonywanych na bieżąco pomiarów oprogramowanie czujnika wyznacza ilość czystego metanu w rurociągu, wykorzystując jedną z dwóch zaimplementowanych metod: uproszczoną lub iteracyjną. Wydatek metanu wyliczany jest w odniesieniu do warunków normalnych $\left(P_{0}=1013,25 \mathrm{hPa}\right.$, $\left.T_{0}=0^{\circ} \mathrm{C}\right)$.

\section{2. Ściana wydobywcza wykorzystana do badań}

Dla uzyskania danych do bieżących analiz przeprowadzono badania w wyrobiskach ściany wydobywczej N-2 w KWK Pniówek [10]. Jest to ściana o wysokiej metanowości, w której prowadzone jest również odmetanowanie. Ściana N-2 przewietrza się sposobem na Y za pomocą głównego strumienia świeżego powietrza doprowadzanego chodnikiem $\mathrm{N}-2$ i pomocniczego (doświeżającego) strumienia podawanego do punktu wylotowego ściany chodnikiem N-3.

Głównym celem badań w rejonie ściany wydobywczej była wstępna ocena możliwości:

- pomiarów ilościowych dla przepływów powietrza i metanu,

- zastosowania metody metanowości kryterialnej do oceny online stanu wentylacji i zagrożenia metanowego w rejonie ściany.

W artykule [14] przedstawiono wyniki badań dotyczące obliczania sieci wentylacyjnej przy zmianach przepływu powietrza, symulacji rozpływu metanu od miejsca podwyższonego stężenia oraz wyznaczania wskaźników metanowości rejonu ściany.

Do wyznaczenia wartości parametrów w poszczególnych chodnikach wykorzystano m.in. anemometry (chodnik N-2, chodnik N-3, dowierzchnia N-3, przekop N-12a), metanomierze (chodnik N-2, chodnik N-3, dowierzchnia N-3), czujniki ciśnienia i różnicy ciśnień (pochylnia $\mathrm{N}-1$, chodnik $\mathrm{N}-3$, chodnik $\mathrm{N}-4$, chodnik N-4a, dowierzchnia N-3). Dodatkowo w chodniku N-3, na rurociągu odmetanowania, zabudowano czujnik wyliczający online wartości wydatku czystego metanu. Badania były prowadzone zarówno z wykorzystaniem czujników dodatkowych (metan, ciśnienie) podłączonych do systemu, jak i ręcznych. Rozmieszczenie czujników i urządzeń pomiarowych zostało przeprowadzone zgodnie z przepisami stosowanymi przez kopalnię i przedstawione na rysunku 5. 


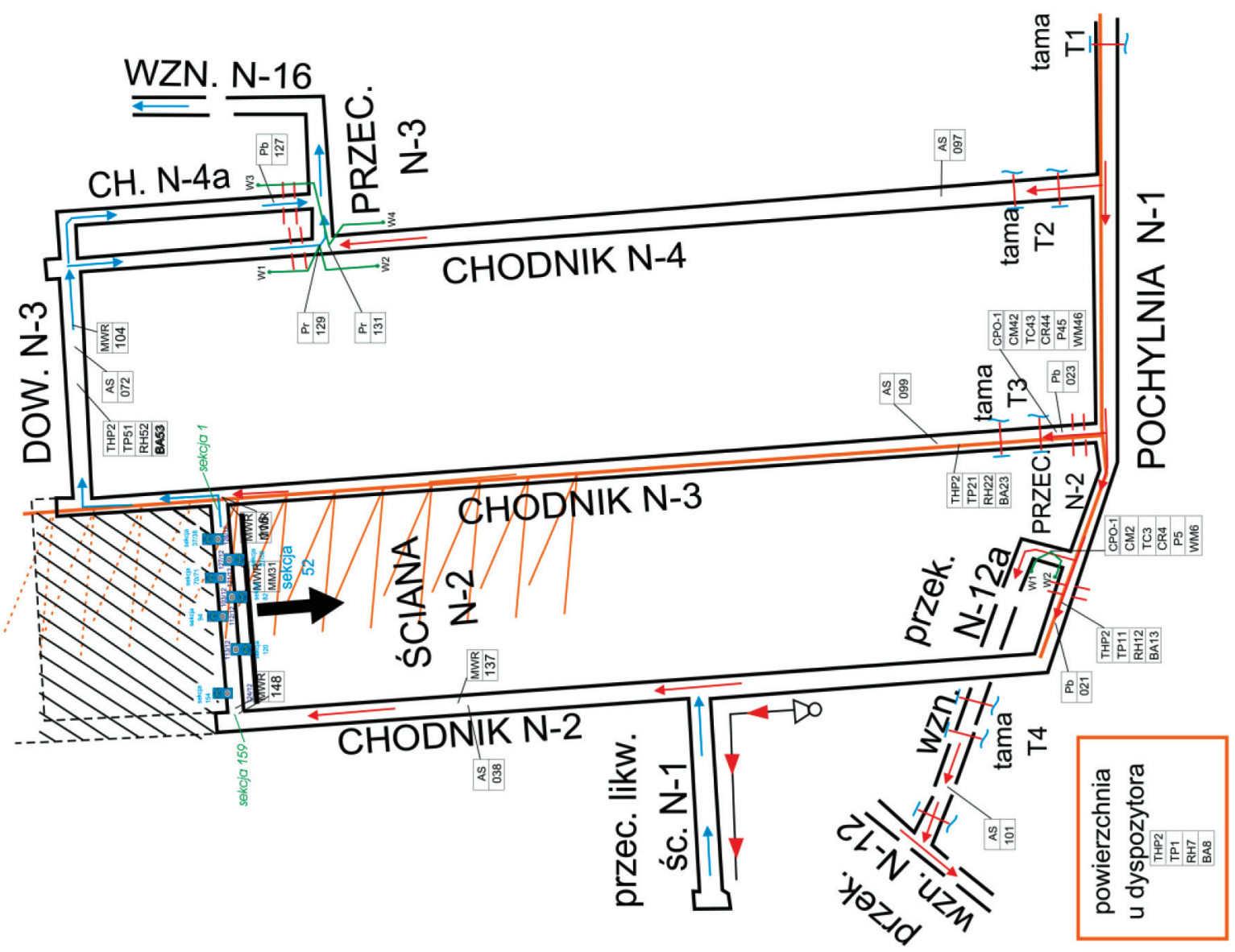

Rys. 5. Sposób rozmieszczenia czujników w rejonie ściany wydobywczej N-2 w KWK Pniówek

Plan badań przedstawiał się następująco:

- zainstalowanie czujników pomiarowych w wybranych punktach rejonu ściany,

- wykonanie eksperymentu biernego (obserwacja i rejestracja parametrów podczas normalnej pracy ściany) oraz eksperymentu czynnego (polegającego na zamknięciu i po kilkunastu minutach otwarciu tamy T1),

- wykonywanie pomiarów przez czujniki prędkości przepływu ręczne i automatyczne, pracujące w systemie monitorowania.

\section{ANALIZA WYNIKÓW BADAŃ}

\subsection{Metanowość wentylacyjna, bezwzględna i kryterialna}

W instrukcji GIG [2] opisano zasady prowadzenia ścian w warunkach zagrożenia metanowego. Wielkością opisującą zagrożenie metanowe w rejonie ściany jest jego metanowość. Obliczana jest ona na podstawie ręcznie zmierzonych wartości stężenia metanu oraz prędkości przepływu powietrza (wydatków powietrza), wykonywanych okresowo przez służby kopalniane. Do scharakteryzowania metanowości w rejonie ściany wydobywczej należy zdefiniować następujące pojęcia:

- metanowość wentylacyjna - bilans wydatku czystego metanu dla rejonu, różnica pomiędzy metanem zmierzonym w prądzie powietrza zużytego a metanem zawartym $\mathrm{w}$ prądzie powietrza świeżego,

- metanowość bezwzględna - suma wydatku wydzielającego się metanu do wyrobisk (metanowość wentylacyjna) oraz wielkości odmetanowania,

- metanowość kryterialna - określa maksymalną metanowość bezwzględną, przy której nie nastąpi przekroczenie dopuszczalnych stężeń w prądzie powietrza zużytego.

Metanowość kryterialna pozwala na całkowitą ocenę zagrożenia metanowego w rejonie ściany wydobywczej na podstawie pomiarów metanu dopływającego 
do ściany $\mathrm{z}$ powietrzem dopływowym (głównym i doświeżającym), metanu wypływającego $\mathrm{z}$ rejonu ściany z powietrzem wentylacyjnym oraz metanu odprowadzanego systemem odmetanowania. Wartość metanowości kryterialnej określa się dla ścian zaliczanych do II, III lub IV kategorii zagrożenia metanowego. W przypadku ścian projektowanych wartości metanowości odnosi się do prognozowanej metanowości bezwzględnej, natomiast w przypadku ścian w ruchu do metanowości bezwzględnej, obliczanej na podstawie pomiarów bezpośrednich.

Wartość kryterialnej metanowości bezwzględnej może stanowić warunek koniecznego zastosowania odmetanowania lub innych środków obniżających wydzielanie się metanu do wyrobisk (np. lutniociągi) w przypadku, gdy obliczona wartość metanowości kryterialnej jest mniejsza niż prognozowana lub rzeczywista metanowość występująca podczas wydobycia w rejonie ściany wydobywczej.

Strumień objętości metanu oblicza się według wzoru [2]:

$$
V=\frac{C_{m} \cdot V_{P W}}{100}\left[\frac{\mathrm{m}^{3}}{\mathrm{~min}}\right]
$$

Kryterialna wartość metanowości bezwzględnej $V_{K R}$ bez doświeżającego prądu powietrza wynosi:

$$
V_{K R}=\frac{C_{m} \cdot V_{s} \cdot k}{100 \cdot n}-V_{D} \quad\left[\frac{\mathrm{m}^{3}}{\mathrm{~min}}\right]
$$

Dla ścian posiadających doświeżający prąd powietrza wartość metanowości kryterialnej wyznacza się z następującej zależności:

$$
V_{K R}=\frac{C_{m} \cdot V_{s} \cdot k}{100 \cdot n}+\frac{V_{p}\left(\frac{C_{m}}{n}-C_{p}\right)}{100-\frac{C_{m}}{n}}-V_{D}\left[\frac{\mathrm{m}^{3}}{\min }\right]
$$

W przypadku prowadzonego w rejonie ściany odmetanowania, obliczoną wartość metanowości $V_{K R}$ należy podstawić do poniższej zależności:

$$
V_{K R-O}=\frac{100 \cdot V_{K R}}{100-E}\left[\frac{\mathrm{m}^{3}}{\mathrm{~min}}\right]
$$

gdzie efektywność odmetanowania $E$ wyznacza się ze wzoru:

$$
E=\frac{100 \cdot V_{O}}{V_{O}+V_{W}} \quad[\%]
$$

$$
\begin{aligned}
& \text { Oznaczenia - wzory (1)-(5): } \\
& C_{m} \text { - dopuszczalna zawartość metanu [\%], } \\
& C_{p}-\text { stężenie metanu w prądzie doświeżającym } \\
& \text { [\%], } \\
& V_{P} \text { - wydatek doświeżającego prądu powietrza } \\
& {\left[\mathrm{m}^{3} / \mathrm{min}\right] \text {, }} \\
& V_{S} \text { - wydatek powietrza w ścianie }\left[\mathrm{m}^{3} / \mathrm{min}\right] \text {, } \\
& V_{D} \text { - wydatek metanu dopływającego do ściany } \\
& {\left[\mathrm{m}^{3} / \mathrm{min}\right] \text {, }} \\
& V_{O} \text { - ilość metanu ujętego przez odmetanowanie } \\
& {\left[\mathrm{m}^{3} / \mathrm{min}\right] \text {, }} \\
& V_{W} \text { - ilość metanu wydzielającego się do wyro- } \\
& \text { bisk }\left[\mathrm{m}^{3} / \mathrm{min}\right] \text {, } \\
& V_{P W} \text { - wydatek powietrza w wyrobisku }\left[\mathrm{m}^{3} / \mathrm{min}\right] \text {, } \\
& k \text { - współczynnik nierównomierności rozkładu } \\
& \text { powietrza w ścianie, } \\
& n \text { - współczynnik nierównomierności wydzie- } \\
& \text { lania metanu. }
\end{aligned}
$$

\subsection{Obliczenia parametrów wentylacyjnych}

Do obliczeń wentylacyjnych wykorzystano program AERO2014 $[6,15]$ opracowany przez Politechnikę Śląską i firmę IFK. Aplikacja zarządza, rozlicza i bilansuje rozplyw powietrza $\mathrm{w}$ kopalnianej sieci wentylacyjnej. Umożliwia modelowanie zmian, przeprowadzanie symulacji, a także dokumentowanie parametrów sieci. Współpracuje ze schematami przestrzennymi i kanonicznymi kopalni w środowisku AutoCAD.

Program AERO2014 oblicza objętościowe wydatki powietrza na podstawie wprowadzonych do modelu numerycznego wartości oporów aerodynamicznych bocznic. Obliczenia oparte są na metodzie Crossa [11] - iteracyjnym wyznaczaniu kolejnych przybliżeń do obliczenia ustalonego rozpływu powietrza w sieciach złożonych $\mathrm{z}$ wielu oczek.

Program obliczeniowy składa się z dwóch modułów:

- Programu Standardowego Wprowadzania Danych (program AERO2014),

- Modutu Graficznego opartego na aplikacji typu AutoCAD. 
Okno programu AERO2014 podzielone jest funkcjonalnie trzema następującymi zakładkami:

- węzły - dane o wprowadzonych do struktury kopalni węzłach,

- wentylatory - parametry pracy wentylatorów, gdzie każdy z nich ma swoją edytowalną charakterystykę, wyliczane są także współczynniki wielomianu charakterystyki urządzenia,

- bocznice - matematyczny model sieci wentylacyjnej kopalni opisujący strukturę połączeń wentylacyjnych pomiędzy poszczególnymi węzłami.

Program AERO2014 umożliwia pracę w trybie dyspozytorskim. Dzięki temu możliwe jest obliczanie parametrów sieci wentylacyjnej na podstawie wskazań czujników pomiarowych. W tym celu w strukturze kopalni definiuje się urządzenia pomiarowe wraz z ich umiejscowieniem: czujniki ciśnienia [7] umieszczone w węzłach oraz czujniki prędkości przepływu powietrza w bocznicach. Możliwe jest także zdefiniowanie czujników gazowych (np. metanomierzy). Do obliczeń wymagany jest także przekrój bocznicy w miejscu pomiaru. Przykładową listę czujników wczytaną w programie AERO2014 przedstawiono na rysunku 6.

Po zdefiniowaniu wszystkich czujników uruchamia się funkcję kontrolującą zawartość w pliku xml ze wskazaniami zdefiniowanych wcześniej urządzeń. Po wykryciu modyfikacji pliku program AERO2014 wylicza nową wartość oporu danej bocznicy oraz oblicza wartości wydatków powietrza w całej kopalni. Nowe wartości zostają wpisane do struktury bocznic. Dzięki odczytom wartości ciśnienia i prędkości przepływu powietrza z systemu monitorowania możliwe jest dynamiczne wyliczanie oporu danej bocznicy wraz z obliczeniem rozpływu powietrza w całej kopalni.

Program sygnalizuje dodatkowo stany ostrzegawcze i alarmowe czujników gazowych, a w przypadku symulacji pożaru uwzględnia wskazania urządzeń w obliczeniach.

\subsection{Obliczanie bieżących wydatków powietrza i metanu w rejonie ściany}

Metanowość obliczana jest na podstawie wartości parametrów uśrednionych. Poważne zagrożenie metanowe występuje jednak podczas osiągnięcia przez niektóre parametry wartości ekstremalnych (wystąpienie jednocześnie wysokich stężeń metanu w powietrzu wentylacyjnym oraz niewystarczającego przewietrzania i niskiej efektywności odmetanowania). Obliczanie metanowości bieżącej przy przyjęciu współczynnika nierównomierności wydzielania metanu $n=1$ powoduje, że we wzorach operujemy wydatkami powietrza i metanu.

Bieżąca metanowość kryterialna określa bezpieczny wydatek metanu powstajacy podczas urabiania przy zmieniających się warunkach przewietrzania, odmetanowania i zawartości metanu w powietrzu dopływającym do ściany. Natomiast bieżąca metanowość bezwzględna to wydatek sumaryczny metanu obliczany na podstawie danych pomiarowych powietrza wylotowego ze ściany i odmetanowania.

Do obliczania wydatku metanu w powietrzu wentylacyjnym rejonu ściany wykorzystano czujniki prędkości powietrza i metanomierze znajdujące się w rejonie ściany $\mathrm{N}-2$. W chodniku N-2 pracował anemometr AS038 oraz metanomierz MM137, w chodniku N-3 anemometr AS099, natomiast w dowierzchni $\mathrm{N}-3$ pomiary rejestrowane były przez anemometr AS072 oraz metanomierz MM104.

Na podstawie przebiegów wartości prędkości przepływu obliczono wydatki powietrza w rejonie ściany N-2. Do obliczeń wykorzystano następujące przekroje poszczególnych chodników:

- chodnik N-2 (anemometr AS038) - 8,63 m²,

- chodnik N-3 (anemometr AS099) - 14,45 m²,

- dowierzchnia N-3 (anemometr AS072 - 13,66 m².

Do obliczeń przyjęto także wartość określonego w [2] współczynnika $k=0,85$, określającego nierównomierność rozkładu prędkości powietrza w ścianie.

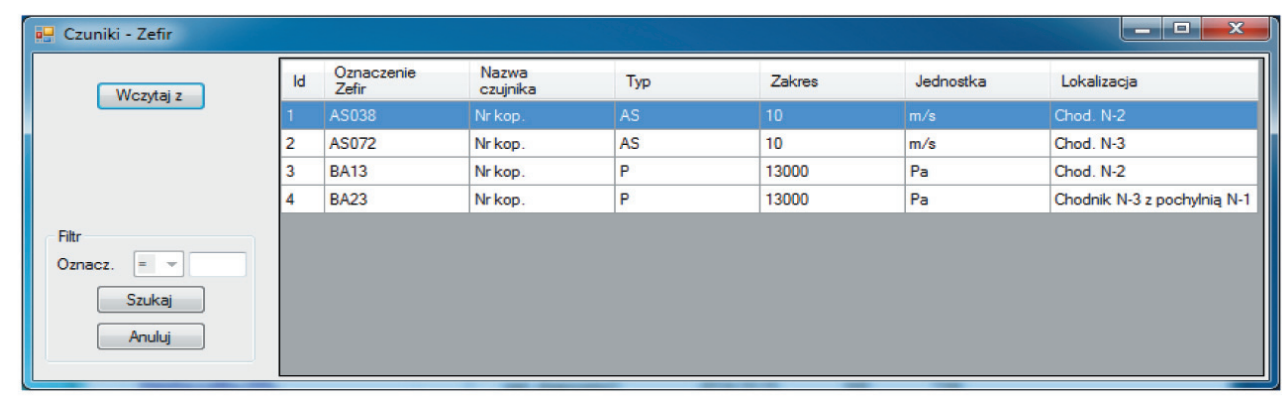

Rys. 6. Okno konfiguracyjne czujników w programie AERO2014 
a)

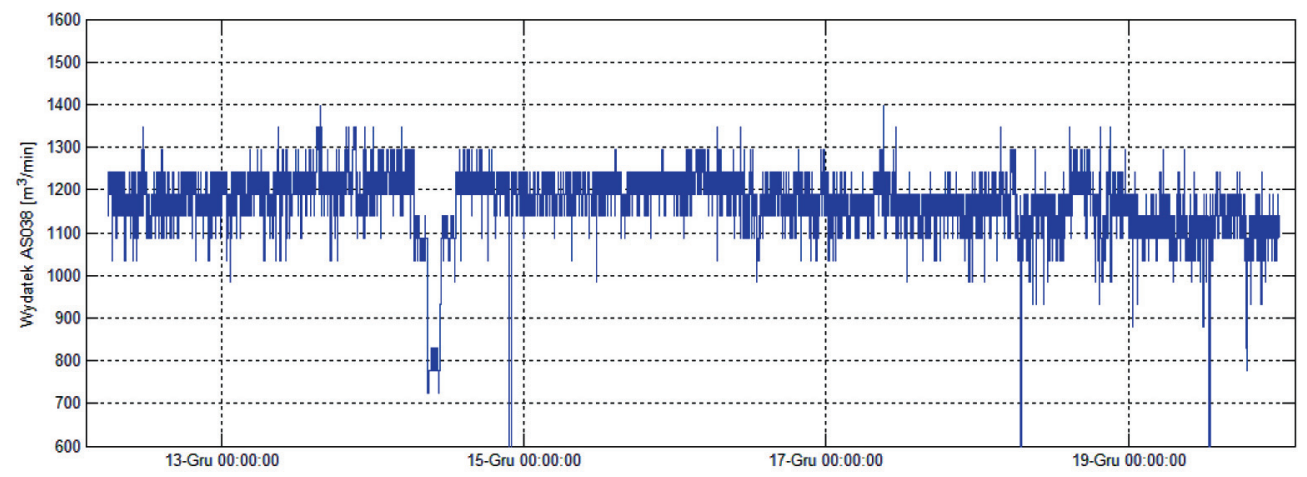

b)

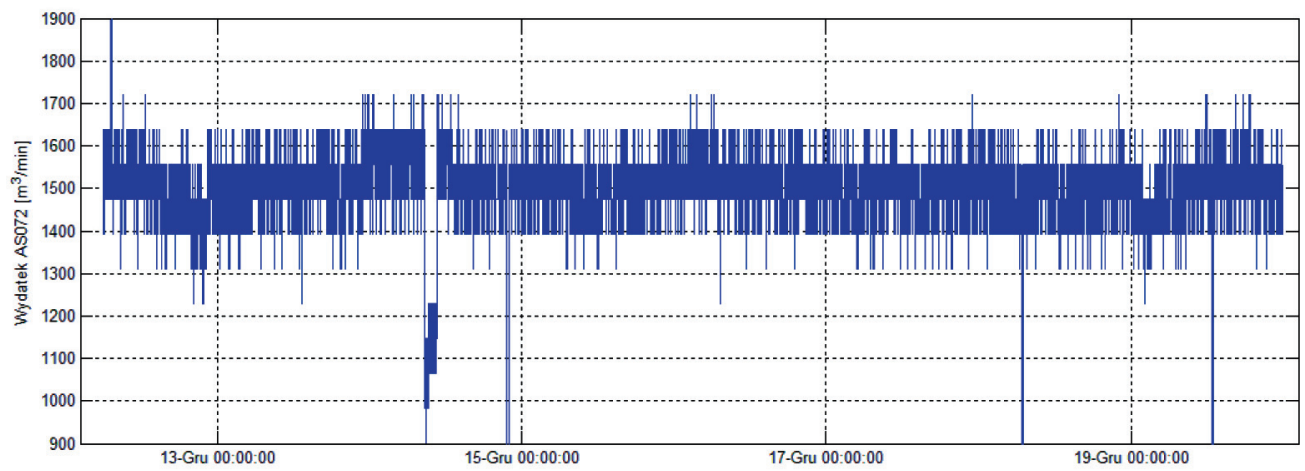

c)

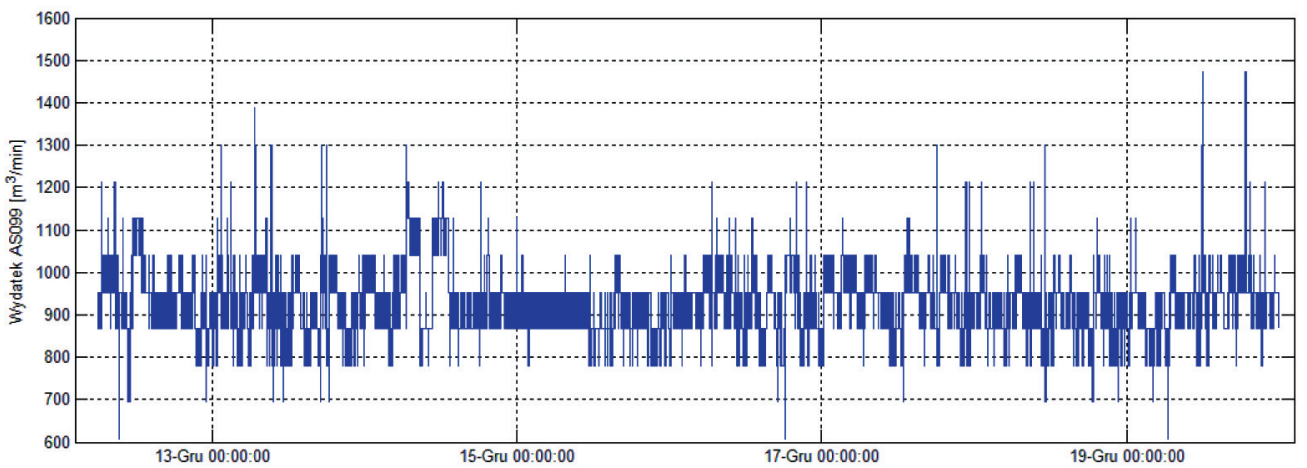

Rys. 7. Wartości wydatków powietrza obliczone na podstawie przebiegów przeptywu powietrza zarejestrowanych przez anemometry: a) AS038; b) AS072; c) AS099

Na rysunku 7 przedstawiono wyznaczone wartości wydatków powietrza na podstawie zarejestrowanych przebiegów prędkości powietrza w rejonie ściany $\mathrm{N}-2$.

Otrzymane średnie wartości wydatku powietrza porównano $\mathrm{z}$ obliczeniami interfejsu AERO, co przedstawiono w tabeli 1 .

Na podstawie tego porównania oszacowano współczynniki przeliczeniowe dla każdego ze stanowisk pomiarowych, wskazujące na różnicę obliczeń programu i rzeczywistych pomiarów (tab. 1). Na rysunku 8 przedstawiono wartości wydatków czystego metanu w powietrzu wentylacyjnym, obliczone na podstawie wydatków powietrza, współczynników przeliczenio- wych oraz procentowego stężenia metanu w rejonie ściany N-2.

Tabela 1

Zestawienie średnich wartości wydatków powietrza otrzymanych z pomiarów, systemu AERO oraz obliczony na podstawie porównania współczynnik przeliczeniowy

\begin{tabular}{|l|c|c|c|}
\hline Nazwa & $\begin{array}{c}\text { Wartość } \\
\text { zmierzona } \\
\text { wydatku } \\
{\left[\mathbf{m}^{\mathbf{3}} / \mathbf{m i n}\right]}\end{array}$ & $\begin{array}{c}\text { Wartość } \\
\text { wydatku } \\
\text { AERO } \\
{\left[\mathbf{m}^{3} / \mathbf{m i n}\right]}\end{array}$ & $\begin{array}{c}\text { Wspól- } \\
\text { czynnik }\end{array}$ \\
\hline Chodnik N-2 & 1169,85 & 1314 & 1,123 \\
\hline Chodnik N-3 & 926,47 & 1566 & 1,690 \\
\hline Dowierzchnia N-3 & 1496,45 & 2880 & 1,925 \\
\hline
\end{tabular}


a)

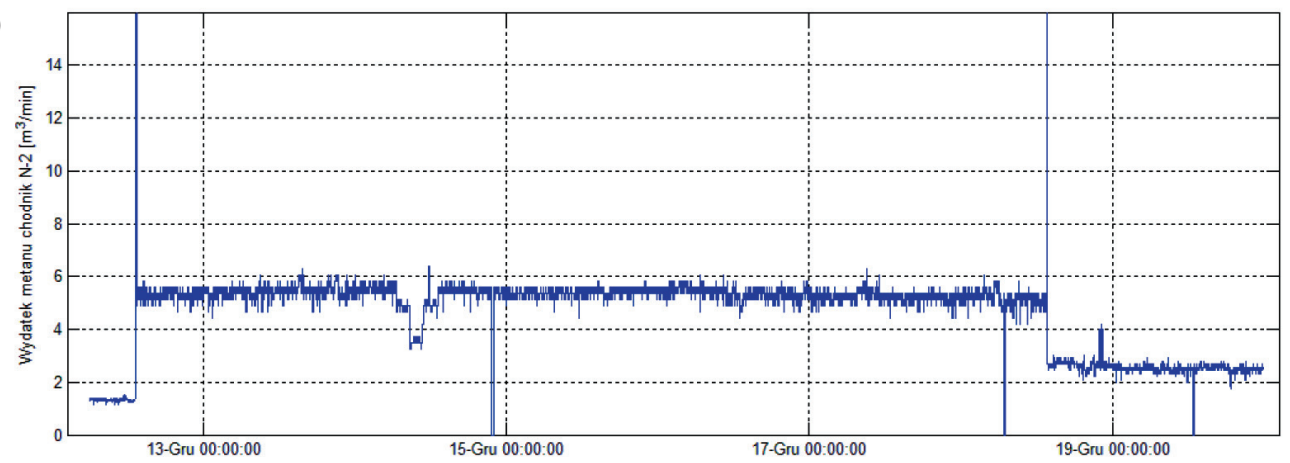

b)

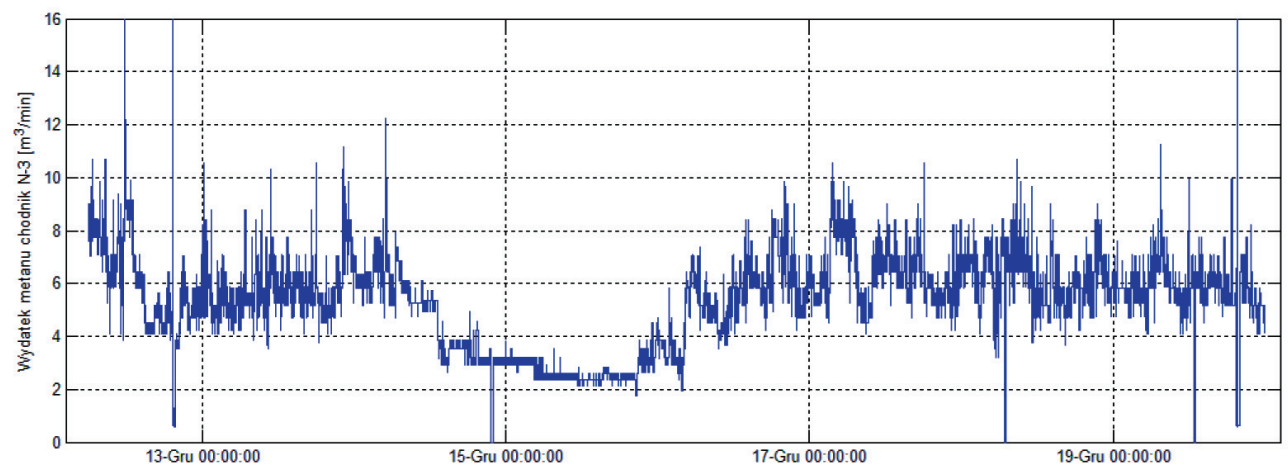

c)

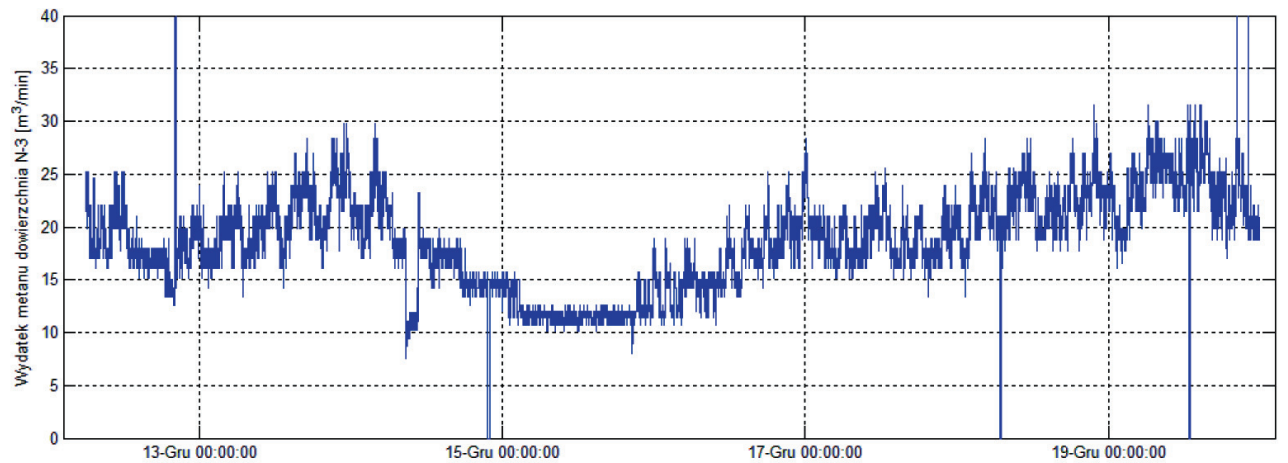

Rys. 8. Wartości wydatków czystego metanu w powietrzu wentylacyjnym w: a) chodniku N-2;

b) chodniku N-3; c) dowierzchni $N-3$

\subsection{Ocena zagrożenia metanowego na podstawie porównania wydatku metanu w powietrzu metanowością wentylacyjną z dopuszczalną}

Wyznaczone wartości wydatków czystego metanu pozwalają na obliczenie metanowości wentylacyjnej w rejonie ściany $\mathrm{N}-2$. Na rysunku 9a przedstawiono przebieg wartości metanowości wentylacyjnej w badanym okresie.

Do obliczenia wartości metanowości kryterialnej, z wykorzystaniem wzoru (3) przyjęto następujące parametry określone w projekcie ściany N-2 [5]:

- dopuszczalna zawartość metanu $C_{m}$ wynosi $2 \%$, a dla odświeżającego prądu powietrza $1,5 \%$,

- współczynnik nierówności rozkładu powietrza w ścianie $k$ wynosi 0,85 ,
- średni przekrój użyteczny ściany wynosi 10,58 m²,

- współczynnik nierówności wydzielania metanu $n$ wynosi 1,0 ze względu na ciągły charakter pomiarów i przeliczeń na podstawie realnych wydatków powietrza i metanu,

- zawartość metanu w prądzie doświeżającym $C_{p}$, wydatek powietrza w ścianie $V_{s}$, wydatek doświeżającego prądu powietrza $V_{p}$ oraz wydatek metanu dopływającego do ściany $V_{D}$ przeliczane na podstawie wskazań zainstalowanych w rejonie ściany N-2 przyrządów pomiarowych.

Ze względu na zastosowanie w rejonie ściany $\mathrm{N}-2$ odmetanowania wartość kryterialną metanowości wylicza się z uwzględnieniem tego procesu na podstawie wzoru (4). Pomiaru wydatku metanu w rurociaggu odmetanowania dokonuje czujnik ZCO [8] pracujący w chodniku N-3. Wartość wydatku wyliczana jest na 
a)

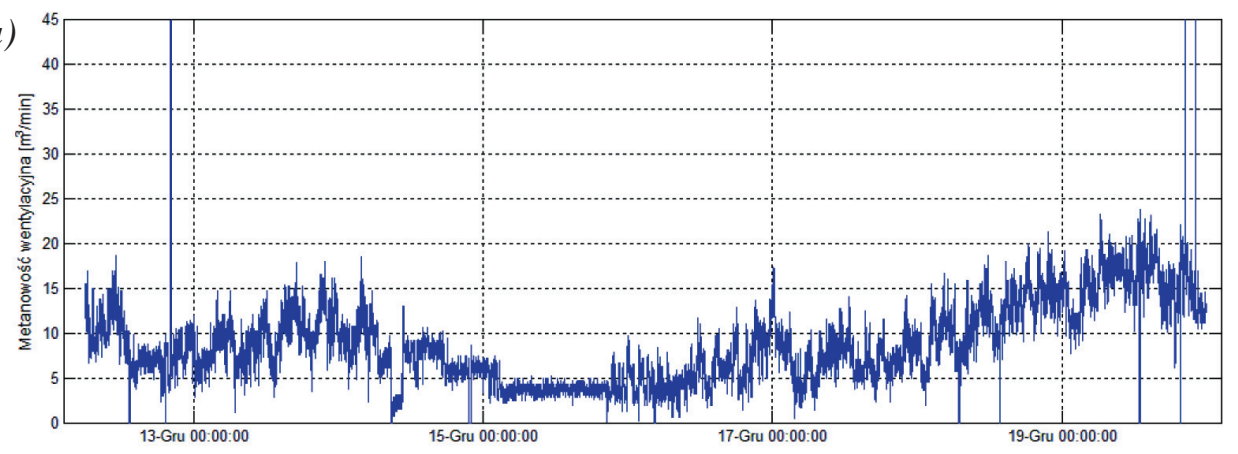

b)

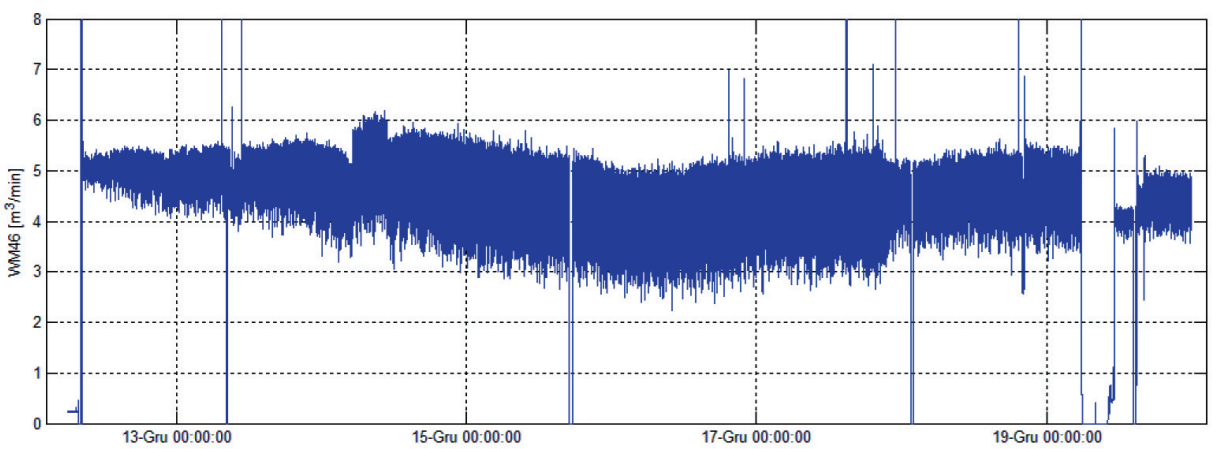

c)

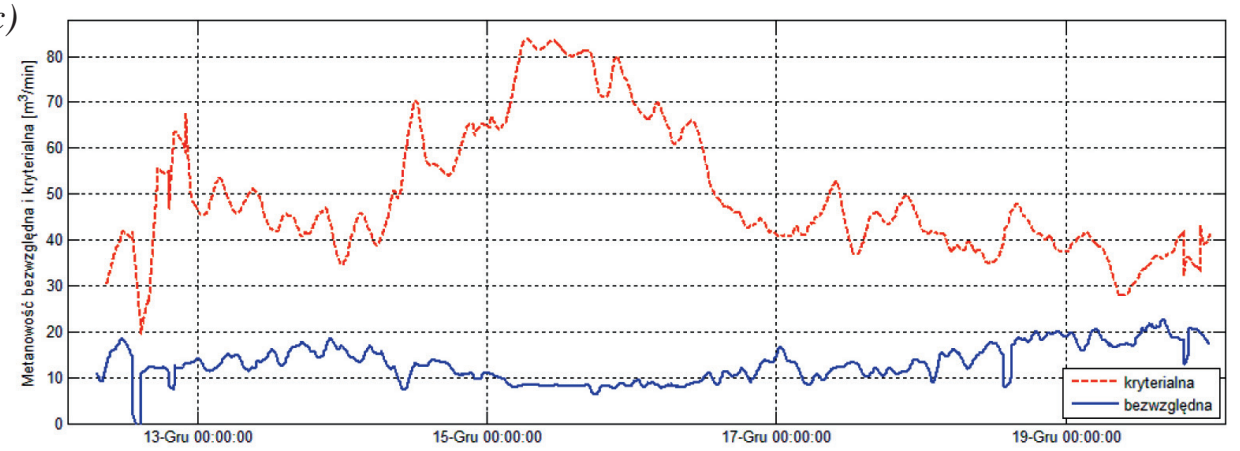

Rys. 9. Metanowość w rejonie ściany N-2: a) metanowość wentylacyjna; b) wydatek metanu $w$ rurociagu odmetanowania; c) metanowość bezwzględna z zaznaczonym poziomem metanowości kryterialnej

podstawie pomiarów parametrów mieszaniny gazu iteracyjnie według normy [19] lub ze wzoru:

$$
V_{C H_{4}}=\% \mathrm{CH}_{4} \cdot 0,011 \cdot a \cdot E \cdot d^{2} \sqrt{\frac{P \cdot h}{s \cdot T}}\left[\frac{\mathrm{m}^{3}}{\min }\right]
$$

gdzie:

0,011 - współczynnik liczbowy,

$a$ - współczynnik przepływu wyliczany na podstawie modułu zwężki pomiarowej,

$E$ - współczynnik ekspansji gazu,

$d$ - średnica otworu zwężki [cm],

$P$ - ciśnienie absolutne w rurociągu [mm $\mathrm{Hg}$,

$h$ - spadek ciśnienia na kryzie pomiarowej [ $\mathrm{mm} \mathrm{H}_{2} \mathrm{O}$ ],

$T$ - temperatura bezwzględna gazu przed zwężką $[\mathrm{K}]$,

$s$ - względna gęstość gazu $\left[\mathrm{kg} / \mathrm{m}^{3}\right]$,

$\% \mathrm{CH}_{4}-$ stężenie metanu [\%].
Zmierzony wydatek metanu w rurociagu odmetanowania przedstawiono na rysunku $9 \mathrm{~b}$. W celu wyliczenia wartości metanowości bezwzględnej zsumowano wskazania metanowości wentylacyjnej oraz wydatku metanu odprowadzanego rurociagami odmetanowania. Na rysunku 9c przedstawiono zarejestrowaną metanowość bezwzględną. Na rysunku zaznaczono także poziom metanowości kryterialnej z uwzględnieniem odmetanowania ściany N-2.

\section{PODSUMOWANIE}

W celu oceny zagrożenia metanowego w rejonach ścian wydobywczych prowadzone były następujące badania:

- pomiary stężeń metanu oraz parametrów wentylacyjnych (ciśnienie i prędkość przepływu powietrza), 
- pomiary parametrów odmetanowania w rurociągu zbiorczym ze ściany (mierzone stężenie metanu, spadek ciśnienia gazu na zwężce pomiarowej, ciśnienie bezwzględne oraz temperatura gazu, które pozwalają na obliczanie aktualnego wydatku przepływu czystego metanu).

Przeprowadzone badania dały wyniki pozwalające na określanie i obliczanie zagrożenia metanowego online na podstawie bieżąco analizowanej metanowości wentylacyjnej i kryterialnej oraz efektywności odmetanowania wykorzystującej pomiary z czujników prędkości przepływu powietrza, stężenia metanu oraz wydatku metanu z rurociągu odmetanowania.

Pomiary prędkości przepływu powietrza dla obliczania wydatków w bocznicach przyścianowych sieci wentylacyjnej przeprowadzane były dwiema metodami:

- metodą ręczną zgodnie z górniczą techniką pomiarową (metoda trawersu ciągłego [4]),

- automatyczną w systemie monitorowania (dokonano pomiaru punktowego przy uwzględnieniu współczynnika rozkładu prędkości powietrza w przekroju wyrobiska).

Wyznaczone różnymi metodami wartości przepływów powietrza w niektórych przypadkach znacznie się różniły. Konieczne będą prace nad opracowaniem charakterystyk dla różnych prędkości powietrza dla typowych miejsc sieci wentylacyjnej. Przy takich pracach pomocne będą również wyniki prac publikowanych przez jednostki badawcze [16-18].

Wyniki badań stanowią podstawę do opracowania:

- struktury i funkcji systemu monitorowania realizującego również wybrane analizy wentylacyjno-gazowe,

- oprogramowania realizującego funkcje analiz.

\section{Literatura}

[1] Pawiński J., Roszkowski J., Strzemiński J.: Przewietrzanie kopalń, Śląskie Wydawnictwa Techniczne, Katowice 1995.

[2] Krause E., Łukowicz K.: Zasady prowadzenia ścian w warunkach zagrożenia metanowego, Instrukcja nr 17 GIG, Katowice - Mikołów 2004.

[3] Miśkiewicz K., Wojaczek A., Wojtas P.: Systemy dyspozytorskie kopalń podziemnych i ich integracja. Wybrane problemy, Wydawnictwo Politechniki Śląskiej, Gliwice 2011.

[4] Roszczynialski W., Trutwin W., Wacławik J.: Kopalniane pomiary wentylacyjne, Wydawnictwo Śląsk, Katowice 1999.

[5] Dokumentacja ściany N-2 w poktadzie 404/2 w KWK Pniówek, Pawłowice 2013

[6] AERO2014: Materiały informacyjne Informatycznej Firmy Konsultingowej.
[7] Broja A., Felka D., Mróz J., Skierś P.: Badania czujników ciśnienia powietrza dla celu ciagtego monitorowania, Konferencja Naukowo-Techniczna EMTECH, Szczyrk 2014.

[8] Broja A., Małachowski M., Felka D.: Monitorowanie parametrów odmetanowania $w$ kontekście ich wplywu na wartości metanowości $w$ rejonie ściany, Materiały Konferencji Naukowo-Szkoleniowej „Zasilanie, telemetria i automatyka w przemyśle wydobywczym. Innowacyjność i bezpieczeństwo". EMTECH, Zakopane 2015.

[9] Felka D., Broja A.: Pomiary parametrów do wyliczenia strumienia objętości metanu w rurociagach sieci odmetanowania, w: Mechanizacja, automatyzacja i robotyzacja w górnictwie: monografia, red. nauk. K. Krauze, Centrum Badań i Dozoru Górnictwa Podziemnego, Katedra Maszyn Górniczych, Przeróbczych i Transportowych AGH, Kraków 2014, s. 72-82.

[10] Dokumentacja projektu europejskiego AVENTO: „Zaawansowane narzedzia do kontroli wentylacji i emisji metanu", Instytut Technik Innowacyjnych EMAG, Katowice 2014-2015.

[11] Cross H.: Analysis of flow in networks of conduits or conductors, „Engineering Experiment Station”, Bulletin No. 286, University of Illinois 1936.

[12] Karty katalogowe oraz strony internetowe producentów urządzeń i czujników pomiarowych: Instytut EMAG (www.ibemag.pl), SEVITEL sp. z o.o. (www.sevitel.pl), EMAG-SERWIS sp. z o.o. (www.emagserwis.pl), MICON sp. z o.o. (www.micon.pl), CARBOAUTOMATYKA S.A. (www.carbo.com.pl), HASO S.C. (haso.pl).

[13] Cierpisz S., Miśkiewicz K., Wojaczek A.: Systemy gazometryczne w górnictwie, Wydawnictwo Politechniki Śląskiej, Gliwice 2007.

[14] Krzystanek Z., Mróz J., Trenczek S.: Zintegrowany system monitorowania $i$ analizy zagrożenia metanowego $w$ rejonie ściany wydobywczej, „Mining - Informatics, Automation and Electrical Engineering" 2016, 1: 64-76.

[15] Knapczyk J., Musioł D.: Wykorzystanie systemu Aero do podniesienia bezpieczeństwa $w$ wyrobiskach górniczych poprzez monitoring wentylacyjny, w: Narzędzia informatyczne wspomagajace prognozowanie i monitoring oraz szkolenia $w$ zakresie zagrożen wystepujacych $w$ kopalniach - teoria i praktyka, red. D. Musioł, P. Pierzyna, Instytut Eksploatacji Złóż Politechniki Śląskiej, Gliwice 2015.

[16] Dziurzyński W., Wasilewski S.: Ocena zagrożenia metanowego w rejonie ściany na podstawie czujników gazometrii oraz symulacji komputerowej przepływu mieszaniny powietrza i meta$n u$, „Przegląd Górniczy” 2012, 12: 28-34.

[17] Wasilewski S.: Kontrola prędkości powietrza $w$ wyrobiskach kopalni w systemach nadzoru dyspozytorskiego, „Przegląd Górniczy" 2013, 7: 1-13.

[18] Wasilewski S.: Monitorowanie zakłóceń parametrów powietrza $w$ systemach dyspozytorskiego nadzoru powstałych $w$ wyniku krótkiego spięcia, „Przeglad Górniczy” 2015, 11: 33-43.

[19] PN-EN ISO 5167-1:2005: Pomiary strumienia ptynu za pomoca zwężek pomiarowych wbudowanych $w$ catkowicie wypetnione rurociagi o przekroju kołowym. Część 1: Zasady i wymagania ogólne.

dr inż. JERZY MRÓZ

mgr inz. DARIUSZ FELKA

mgr inż. ADAM BROJA

dr inż. MARCIN MAEACHOWSKI

Instytut Technik Innowacyjnych EMAG

ul. Leopolda 31, 40-189 Katowice

\{J.Mroz, D.Felka, A.Broja,

M.Malachowski\}@ibemag.pl 